\title{
REVIEW
}

\section{Quantitative sampling of soft-bottom sediments: problems and solutions}

\author{
Sven Blomqvist \\ Department of Systems Ecology, Section Marine Ecology, and Department of Geology and Geochemistry,
} Stockholm University, S-10691 Stockholm, Sweden

\begin{abstract}
Since the pioneering attempts to obtain quantitative soft-bottom sediment samples at the beginning of this century, many different devices for sampling soft bottoms have been presented. Most techniques, however, yield semi-quantitative samples only. For studies dealing with certain aspects of microlayering, freezing in situ seems to be a good method. In more general studies, quantitative samples appear to be best obtained using instruments based on the coring principle. Improper handling or faulty design of the coring device, however, results in unrepresentative samples. Major factors in bias are (1) loss of surficial sediments, (2) redistribution, resuspension and loss of enclosed sediment, (3) core shortening, and (4) repenetration. Frictional drag and consequent smearing against the coring tube is also a potential source of error General design features improving the reliability of sampling are a supporting stand and, when dealing with open corers, an unimpeded water flow through the sample compartment. Box corers appear best suited for sampling certain macrofauna and sediments of coherent and silty/sandy character. Adequately designed and properly operated tube corers are the most versatile instruments at present. A general concern, however, is that coring tubes enter and penetrate the sediment carefully and slowly. Under favourable conditions, an open-barrel gravity corer can be used for sampling the unshortened upper layer, in combination with a larger box corer and subsequent piston-coring technique for sampling the underlying layers. When sampling under less favourable conditions, or when extreme care is required, the corer must be based on a structure with a supporting stand, which permits the device to settle on the bottom before the coring tubes enter the sediment. Mounting an underwater video camera as a standard on such devices is recommended since it enables visual inspection and recording of each sampling. Other tested means and promising improvements in instrument design to improve sampling reliability are also discussed.
\end{abstract}

\section{INTRODUCTION}

It is now rather well understood by benthic ecologists that their subject is urgently in need of some introspection and in particular that its technique and methodology do not match the scope and importance of its subject-matter, which embraces the study of the fauna living on perhaps four-fifths of the surface of the planet.

A. R. Longhurst (1964)

Acquisition of representative soft-bottom samples is the fundamental prerequisite for much research in aquatic ecology, geochemistry and environmental science, as well as for related historical investigations, conducted in marine and limnic environments. The first recorded attempts to obtain quantitative samples date from the beginning of this century (Petersen \& Jensen 1911, Petersen 1913, Ekman 1915, Naumann 1917). Today, the demand for quantitative benthic samples is evident in countless studies dealing with e.g. abundance of benthic organisms, nutrient and metal dynamics, fate of pollutants, historical monitoring, etc. False conclusions are an obvious risk if such studies are based on biased field samples.

The widely felt need to obtain soft-bottom sediment samples has led to the development of a large variety of techniques for sampling soft bottoms. The literature on this topic is therefore extensive (see bibliographies by McIntyre 1970, Elliott \& Tullett 1978, 1983, Rosenberg 
1978), and a wealth of reviews has been published (e.g. Apstein 1907. Steiner 1919, Pratje 1924, 1938, 1950a, Lundqvist 1925, Naumann 1930, Wasmund 1932, Hough 1939, Twenhofel \& Tyler 1941, Welch 1948, Hvorslev 1949, Holme 1951, 1964, 1971, Dietz 1954, Gunter 1957, Thorson 1957, Barnes 1959, Cummins 1962, Fægri \& Iversen 1964, Hopkins 1964, Longhurst 1964, Wright et al. 1965, Brinkhurst 1967, 1974, Rosfelder \& Marshall 1967, Richards \& Parker 1968, Schlieper 1968, Bouma 1969, Sly 1969, 1981, Bailey 1971, Chodorowski 1971, Hulings \& Gray 1971, Kajak 1971, McIntyre 1971a, Reys \& Salvat 1971, Wells 1971, Noorany 1972, Shepard 1973, Dybern et al. 1976, Clarke 1977, Hellawell 1978, 1986, Moore \& Heath 1978, Southwood 1978, Resh 1979, Elliott et al. 1980, Wright 1980, Håkanson \& Jansson 1983, Thiel 1983, Downing 1984, Eleftheriou \& Holme 1984, McIntyre \& Warwick 1984, Aaby \& Digerfeldt 1986, Schwoerbel 1986, Fleeger et al. 1988, Elmgren \& Radziejewska 1989). Unfortunately, most of these reviews are antiquated or fairly brief compilations, based on a limited set of information only. There are few thorough reviews, and detailed evaluations of sampling problems are even more scant. Therefore, despite the large number of surveys published, it is still difficult to get an overview of the state of the art in quantitative sampling of softbottom sediments. The present review attempts to fill this need by providing an updated, condensed summary of factors constraining the quantitative sampling of softbottom sediments. Various impact characteristics of the devices employed causing sample bias are specifically addressed. This review is primarily based on studies conducted during the last $25 \mathrm{yr}$, and also includes a section on guidelines for improving the design of devices and on further instrument development.

\section{CHOICE OF SAMPLING DEVICE}

The use of trawls, sledges, dredges, suction samplers, grabs of snap (clamshell), scoop or bucket design, corers of impact or hydrostatic type, etc., results in various degrees of semi-quantitative sampling only (e.g. Elliott \& Drake 1981a, b, Drake \& Eliott 1982, Downing 1984, Eleftheriou \& Holme 1984). In practice, only bucket grabs provide reasonably accurate quantitative samples of soft bottoms. Properly shaped buckets and the design of the closure mechanism are, however, of particular significance for reliable sampling. The buckets must be shaped in such a way that they enter the sediment perpendicularly on impact, and it is important that the closure mechanism be designed so that it does not raise the sampler during closure and thereby interfere with the sediment layer initially penetrated (Riddle 1989). Also, the grab has to conform to the hole dug by the leading edge of the jaws so as not to compress the sediment or cause the sampler to rise on closure (Ankar 1977, Riddle 1989).

Experimental studies on the bite profile of grabs, such as that of the Petersen grabs (Petersen \& Jensen 1911, Petersen 1913), the Ponar grab (Powers \& Robertson 1967), the Smith-McIntyre grab (Smith \& McIntyre 1954) and the Day grab (Eleftheriou \& Holme 1984), suggest that unequal depth sampling per unit surface area is a common source of error when using this type of grab (Gallardo 1965. Elliott \& Drake 1981a, Riddle 1989). The van Veen grab (van Veen 1933) seems to be the bucket grab achieving the most rectangular bite (Gallardo 1965, Lie \& Pamatmat 1965, Ankar 1977, Riddle 1989); however, oblique and asymmetrical closing (which happens particularly easily with a drifting boat and a long-armed instrument), and a sampling performance or sampling efficiency which varies with substrate texture and certain design details (arm length, type of rigging, size of bucket windows), are insidiously biasing factors (Ursin 1954, Birkett 1958, Beukema 1974, Christie 1975, Ankar 1977, Ankar et al. 1979, Andersin \& Sandler 1981, Riddle 1989). This necessitates extreme care when evaluating studies based on sampling by a van Veen grab. It also suggests that evaluation of samples collected by other grabs is even more difficult, particularly when stations with different bottom characteristics are compared.

Sediment freezing in situ can provide quantitative samples for studies on e.g. microlayering in lakes (see reviews by Wright 1980, Renberg 1982, 1986a, Saarnisto 1986). Sampling the uppermost surficial layers using this technique, however, requires particular care. A device presented by Renberg (1981a) seems to be the best instrument available for freeze-sampling. It can be operated remotely from a fixed foundation (i.e. freely from an ice cover, if it occurs; otherwise less freely from a jetty or similar structure), or for sampling in a recovered box corer (own unpubl. obs.). In the latter case, it should be noted that soft surficial sediments in a box corer are easily disturbed (e.g. Blomqvist 1990, and further discussion below). Unfortunately, freezing is neither a versatile nor a quick technique, nor is it usable in more general bottom-sampling involving enclosure of sediment samples (Rutledge \& Fleeger 1988 ) or collection of benthic macrofauna, which restricts application of this technique. However, reports of detailed palaeolimnological studies of uppermost sediments (Renberg 1981b, 1986b, c, Renberg \& Wik 1985) demonstrate the usefulness of properly performed freeze-sampling when dealing with fine-scale stratification

In essence, all bucket grabs are based on a construction of jaws which close more or less semi-circularly. Therefore, sediment layers below the initial penetra- 
tion depth are inevitably semi-quantitatively sampled. Sampling performance and sampling efficiency also vary among grab designs and among different bottom substrates. Freeze-sampling is a technique which can provide certain quantitative sediment samples for e.g. studies of microlayering, but it has practical restrictions which preclude its more general use. A sampling device with which truly quantitative soft-bottom samples may be taken must have a definite sampling area which encloses the corresponding underlying sediment column, retains the sample and minimizes disturbances of the sediment during sampling and recovery. Consequently, such sampling must involve either (1) openbarrel gravity corers (sensu Emery \& Hülsemann 1964), (2) box corers (which are open rectangular gravity corers) or (3) piston corers.

\section{Limitations and biasing factors}

A number of factors can adversely affect samples collected by corers

(1) Unimpeded water flow through the corer during descent is important. Otherwise, a hydraulic shock wave (bow wave) created in front of the orifice can wash away flocculent or easily resuspended surficial sediments before the corer reaches the sediment surface. This source of error has been reported for grabs (Wigley 1967, Flannagan 1970, Ankar 1977), openbarrel gravity corers (McIntyre 1971b, Elmgren 1973. Baxter et al. 1981, Jensen 1983, Leonard 1990), box corers (Jumars 1975a, b. Thiel et al. 1988/1989) and piston corers (McCoy \& von Herzen 1971, McCoy 1972. 1980, Stowe \& Aksu 1978).

(2) Gravity corers not equipped with a supporting stand tilt readily on the bottom, which may result in redistribution and resuspension of enclosed sediment and in loss of material (Blomqvist 1985, 1990). Also, the sampler may sink down too deeply to provide a representative sample (e.g. Wundsch 1924, Lundbeck 1926, Valle 1927. Flannagan 1970, Blomqvist 1990).

(3) The sample can be disturbed during the closing operation and withdrawal from the sediment (Blomqvist 1985), and during retrieval. Rotation of a corer during retrieval causes shear stress on the sediment, with ensuing resuspension and redistribution, particularly of soft surficial sediments. Since rate of entrainment increases with sample area, instruments enclosing a larger area of surface sediments produce disturbance more easily than do corers with narrow tubes (Blomqvist 1990). Resuspension and redistribution of sediment samples obtained by larger corers (e.g. Elmgren 1973) might also make subsequent subsampling complicated (Rutledge \& Fleeger 1988). In corers without a secure lid-locking mechanism, resuspension may even result in loss of sediment and organisms (Blomqvist 1990).

(4) Sediment core shortening in open-barrel corers. i.e. the difference between depth of sediment penetration by the coring tube and interior length of the core, is a phenomenon which may severely bias the sampling (Naumann 1917, Lundqvist 1922, 1923, Pratje 1934. 1935, 1950a, b, Emery \& Dietz 1941, Piggot 1941, Hvorslev \& Stetson 1946, Hvorslev 1949, Richards 1961, Emery \& Hülsemann 1964, Harrison et al. 1964, Inderbitzen 1968, Hongve \& Erlandsen 1979, Burnett 1981 , Evans 1982, Lebel et al. 1982, Weaver \& Schultheiss 1983, Blomqvist 1985, Nevissi et al. 1989). A common misconception is that this phenomenon results from compaction due to loss of interstitial water. The sediment column obtained would thus be uniformly representative with respect to solid components, albeit comprised of a shorter core with lower water content. However, as stated long ago (Pratje 1934, 1950a, Emery \& Dietz 1941, Piggot 1941, Hvorslev \& Stetson 1946. Hvorslev 1949), and corroborated further by later experiments (Hongve \& Erlandsen 1979, Evans 1982, Lebel et al. 1982, Blomqvist 1985), core shortening principally involves deficient entry of sediment.

Core shortening results from discriminate sampling during penetration of the coring tube. Physically, it is due to friction of sediment against the inner tube wall, causing thinning by lateral extrusion in front of the corer. As the drag resistance alters with depth, the penetrated sediment bed is differently represented (Piggot 1941, Weaver \& Schultheiss 1983, Blomqvist 1985). Between-station variations in the physical character of sediments also result in varying degrees of core shortening (cf. Pratje 1935, 1950a, Emery \& Dietz 1941). Clayey silty sediments are shortened more than are light, unconsolidated organic sediments. If soft sediment is overlaid by stiffer matter, however, the former is more thinned than the latter (e.g. Pratje 1934, Piggot 1941, Hvorslev 1949, Hongve \& Erlandsen 1979, Weaver \& Schultheiss 1983). This produces a bias in samples which is difficult to detect (cf. Kallstenius 1958: p. 9-10). The problem is further complicated by the fact that the initiation of core shortening is related to sampling tube diameter, and the degree of shortening is influenced by the penetration velocity and diameter of the coring tube employed (Emery \& Dietz 1941, Hvorslev 1949, Hongve \& Erlandsen 1979, Evans 1982, Blomquist 1985). The use of double-sided tape placed on the outside wall of the corer so as to allow corrections based on the mud line on the tape, as suggested by Håkanson \& Jansson (1983: p. 32), has been found an unreliable method (own in situ obs.). In essence, it is most important to be aware of core shortening when evaluating data from sediment coring; it is a treacherous phenomenon which sometimes causes 
severe bias. To properly record and correct for core shortening in samples is most difficult, and seems in practice often impossible.

(5) The free-falling piston corer is an instrument developed to counteract the influence of friction against the inner wall of the coring tube. The use of a piston, derived from a method employed in terrestrial clay sampling (Olsson 1925; see also Olsson 1938), in combination with an adapter permitting tripping and free-fall from just above the bottom (Kullenberg 1944, $1945,1947,1955)$ has become a much-used underwater technique. However, such piston corers also have serious drawbacks. Rotation and tilting of the sampler upon impact have been reported, as well as core shortening and sucking in of sediment; the sedimentary layers of the core may be deformed, and the uppermost soft sediments are often seriously disturbed and may be entirely missing (Richards 1961, Ross \& Riedel 1967. Bouma \& Boerma 1968, Chmelik et al. 1968, Inderbitzen 1968, McCoy \& von Herzen 1971, McCoy 1972, 1980, 1985, Hollister et al. 1973, Seyb et al. 1977, Moore \& Heath 1978, Stowe \& Aksu 1978).

(6) The frictional downward dragging of overlying sediment, resulting in smearing against the inside of the coring tube, might render direct visual inspection of the stratigraphy impossible and, particularly in studies dealing with trace components, might also create a contamination problem (e.g. Wrath 1936, Igarashi et al. 1970, Stowe \& Aksu 1978, Harvey et al. 1987, Chant \& Cornett 1990).

(7) Re-penetration may easily lead to misinterpretations, such as e.g. apparent cyclicity of sedimentary records when using open-barrel gravity corers (McCoy 1972, 1980, Moore \& Heath 1978, Weaver \& Schultheiss 1983). Rolling and pitching of the vessel from which the samples are taken may entail a related problem when the sampler hits the bottom and causes disturbance before the corer actually enters the sediment (Hessler \& Jumars 1974, Snider et al. 1984).

\section{DISCUSSION}

Today, more than 25 yr after the statement by A. R. Longhurst quoted at the beginning of this review, knowledge about constraining mechanisms and biasing factors in aquatic soft-bottom sediment sampling has been significantly improved, and progress in instrumental design has also been made. At present, the main problems appear in fact not so much to be conceptual in nature as to involve lack of appreciation of these factors' significance in the quality of samples obtained. This is remarkable, considering that biased sedimentological field samples will inevitably compromise the quality of the research based on them.

\section{Features to consider in selection and design of instruments}

The instruments best suited for quantitative sampling of soft-bottom sediments appear to be those based on the coring principle. If large single samples are needed, a properly operated and adequately designed box corer might be appropriate for sampling benthic macrofauna, and infauna in particular (Blomqvist 1990). Also, for certain geochemical studies a box corer is expedient (e.g. Ingri 1985). However, in studies dealing with unconsolidated surficial or flocculent sediments, enclosure and segregation of individual samples in situ is recommended, rather than subcoring after retrieval of a large corer (Rutledge \& Fleeger 1988, 1989). The unintentional disturbance and resuspension which easily happen during sampling and hauling also emphasize the importance of properly locking corer lids (Blomqvist 1990)

Acquisition of individual sediment samples usually involves tube coring, by either a single or a (simultaneously penetrating) multiple corer. For reliable sampling gentle, slow entry and penetration of the coring tube into the sediment bed are essential in order to prevent loss of surficial sediments (cf. McIntyre 1971b, Elmgren 1973, Baxter et al. 1981, Jensen 1983, Leonard 1990), obviate oblique impact, and minimize core shortening (Blomqvist 1985) or any associated core deformation (e.g. Leonard 1990). The lower end of the coring tube has to be sharply tapered on the outside to provide an effective sampling area similar to the inside crosssectional area of the tube (cf. Livingstone 1990) and also to facilitate penetration. A supporting stand (e.g. Barnett et al. 1984, Blomqvist \& Abrahamsson 1985) is recommended to prevent the sampler from tilting and from sinking too deeply when settled. Moreover, a stand allows a damper to be mounted, ensuring slow entry speed of the coring tube (Craib 1965, Barnett et al. 1984); it may also be beneficial by absorbing impact and thereby protecting the coring assembly, if the device hits against the vessel during deployment.

It is important to consider core shortening when using open tube corers. A large coring-tube diameter reduces shortening (Emery \& Dietz 1941, Hongve \& Erlandsen 1979, Evans 1982, Blomqvist 1985) and hence is preferable. Friction against the wall of the coring tube may be considerable, in practice making sampling with longer cores virtually impossible due to plugging; the sampling tube and its core act like a solid rod and merely displace the sediment as the corer proceeds (Pratje 1934, Piggot 1941). Since the degree of shortening varies with penetration velocity and the physical character of the sediment sampled, the importance of this phenomenon is usually very difficult to evaluate. Determining the dimensions of coring 
tubes based on clearance and area ratios derived in terrestrial soils by Hvorslev (1949: p. 105-108) to overcome or minimize the problem, as is commonly done (e.g. Richards \& Keller 1961, Kögler 1963, Meischner \& Rumohr 1974, Axelsson \& Håkanson 1978), is unreliable. As a general rule, caution must be exercised when considering sediments below the unshortened, topmost layer of samples collected by open tube corers (cf. Blomqvist 1985: p. 610, Fig. 6).

Remotely operated multiple corers of various designs have been described (Krogh \& Spärck 1936. Holme 1964, Willemoës 1964, Fowler \& Kulm 1966, Hamilton et al. 1970, Hakala 1971, M. L. Jones cited in Hulings \& Gray 1971, Kemp et al. 1971, Milbrink 1971, Maitland \& Morris 1978, Bakanov 1979, Barnett et al. 1984, Chandler et al. 1988). Such devices can save much sampling time by providing more sediments per descent than do ordinary single corers and by providing samples in replicate, obvious advantages in many studies. It must be noted, however, that the different cores of a multiple corer are not independently and randomly allocated samples equivalent to repeated lowerings by a single corer (Elmgren \& Radziejewska 1989), but rather represent nested 2-stage, pseudoreplicates (sensu Hurlbert 1984) of the same sampling unit. Therefore, when dealing with data of multiple corers it must be considered that the multiple samples of a lowering do not increase the number of degrees of freedom available for testing with inferential statistics (e.g. Yates 1981, Hurlbert 1984)

\section{CONCLUSIONS}

A judicious choice of sampling device always depends on the objectives of and options available in a particular study. The requirement of unimpeded water flow through the corer to obviate formation of a bow wave in front of the sampler is, however, a common need. The box-coring technique suffers from a number of inherent difficulties and shortcomings. The sampling reliability of box corers can, however, be significantly improved if the device is furnished with a supporting stand and a mechanism which secures the lids during ascent (Blomquist 1990)

Subsampling of unconsolidated or flocculent layers in box corers when brought on board is not recommended. Sectioning of the sample as the device enters the sediment, similar to the 'vegematic' subcoring technique suggested by Jumars (1975a) or the arrangement described by Snider et al. (1984), is a plausible way of avoiding this problem. However, a subcoring design by Fuller \& Butman (1988), related to the technique described by Jumars (1975a), seems inadvisable since it implies restricted water flow through the box corer. Impeded water flow is, in fact, the most immediate ground for objection to subcoring configurations mounted inside box corers. Bow-wave disturbance related to the rim of the box corer is also reported (Jumars $1975 \mathrm{a}, \mathrm{b}$ ). Improvements in design, including lids which lock the individual subcorers after penetration, and further experimental studies evaluating the reliability of this type of subsampling in box corers are therefore needed. At present, box corers can be reliably used mainly for bulk sampling of coherent sediments and some silty and sandy deposits, as well as for collection of certain macrofauna.

Under favourable conditions (calm sea and shallow water, sheltered inshore areas, studies in small lakes, etc.) an adequately designed and properly operated barrel corer (Blomquist \& Abrahamsson 1985) is to be recommended for sampling the top few centimetres, in combination with a larger box corer and subsequent piston-coring (Blomqvist \& Boström 1987) to sample the underlying layers. When sampling under less favourable conditions or when extreme care is required - as in certain deep-sea studies, and in quantitative collection of meiobenthos and nanobenthos (sensu Thiel 1983) and pollutants (Frithsen et al. 1983, Jumars \& Eckman 1983, Thiel 1983, Snider et al. 1984, Rudnick et al. 1985) as well as bacteria and compounds in the upper sediment layer - the corer must be based on a structure with a supporting stand, which permits the device to settle on the bottom before the coring tubes enter the sediment (e.g. Baxter et al. 1981, Pfannkuche 1985, Gooday 1986, 1988, Thiel et al. 1988/1989).

Principles in the design of a tube-coring instrument, introduced by Craib (1965), and later elaborated into the Scottish Marine Biological Association (SMBA) multiple tube corer by Barnett et al. (1984), are of particular interest in this context. Both the Craib corer and the SMBA corer are furnished with a supporting stand and sediment penetration does not start until the device has come to rest on the bottom. The coring operation proceeds slowly, as it is controlled by hydraulic dampers. In fact, the SMBA corer (Barnett et al. 1984) seems to be the best device available for general sampling of open-sea, soft-bottom sediments at present (see also Barnett \& Watson 1989).

However, both these devices also have shortcomings. The Craib corer obtains only a short sediment sample $(10$ to $15 \mathrm{~cm})$ of narrow diameter $(5.7 \mathrm{~cm})$, and is not appropriate for open-sea conditions (Barnett et al. 1984). A practical shortcoming of the SMBA multiple corer is that it is unwieldy (height $3.5 \mathrm{~m}$, framework diameter $2.4 \mathrm{~m}$ ) and heavy, and hence requires research vessels of considerable size and derrick capacity. Further development of this device to a more suitable size is, in fact, a prerequisite for its use in practical field work, as are trials with different sediment types. Because both of 
these instruments are open tube corers, of course, sediment samples collected by these or similar devices can be marred by core shortening, at least if the intention is to obtain long cores.

\section{Looking ahead}

In the future, the need for reliable samples of delicate soft-bottom sediments can be expected to increase. Therefore, further development of dependable instruments providing representative samples under varying sampling conditions and circumstances (water depth, sediment character, sea state/weather, boat size and available facilities such as pulley, winch, derrick, etc.) is imperative. The instruments conforming best to this demand are those based on box- and tube-coring techniques. For several reasons it is advisable to furnish the core samplers with a supporting stand. In addition to preventing tilting, this allows for construction of devices resting on the bottom before actual sediment sampling starts. Also, it permits a damper to be mounted, ensuring slow, predetermined entry speed during coring. Properly deployed, this type of device can operate irrespective of sea roughness and vessel mation.

A problem which remains to be solved is the design of a remotely operated tube corer which prevents disruptive bow-wave disturbance of upper sediments as well as biasing core shortening. Since piston-coring can almost eliminate core shortening (Blomqvist \& Boström 1987), the application of this technique to corers furnished with both a supporting stand and a hydraulically dampered coring assembly might be a possible solution to the problem. A core-conveying sleeve (Kjellman et al. 1950, Livingstone 1967, Rosfelder \& Marshall 1967. Chmelik et al. 1968) is another technique which, in addition to preventing core shortening, can also minimize dragging and smearing of the sample against the wall of the coring tube.

The use of remotely operated devices normally mean that the sampling operation cannot be visually observed. The results of earlier studies reporting actual observations from sampling trials (Wigley 1967, Flannagan 1970, McCoy \& von Herzen 1971, McCoy 1972, 1980. Ankar 1977, Seyb et al. 1977. Blomquist 1985 1990) illustrate the importance of visual evaluations of the samplers' performance. This suggests that it is advisable to document the performance photographically, to corroborate asserted sampling qualities, when describing novel devices. Such documentation is in fact very seldom included (Barnett et al. 1984, Blomqvist \& Abrahamsson 1985).

Finally, it is also recommended when sampling at sea or in otherwise unfavourable conditions that an under- water film camera and a light source be mounted as standard accessories on the stand of the device. A video camera might in fact be preferable, since it permits immediate inspection without film development. This would enable recording and supervising of each sampling procedure and make it possible to exclude not only clearly inferior samples but also samples less obviously biased by bow wave, jerk and jostle, or core shortening. Routine in situ monitoring of sampling would also provide a record of the performance of devices used under various conditions, and hence promote further development of reliable and dependable soft-bottom sampling instruments.

Acknowledgements. I am grateful to Kurt Boström, Ragnar Elmgren and Klaus Koop for constructive comments on the manuscript. Financial support was received from the Swedish Environmental Protection Agency.

\section{LITERATURE CITED}

Aaby, B., Digerfeldt, G. (1986). Sampling techniques for lakes and bogs. In: Berglund, B. E. (ed.) Handbook of Holocene palaeoecology and palaeohydrology. John. Wiley \& Sons, Chichester, p. 181-194

Andersin, A.-B., Sandler, H. (1981). Comparison of the sampling efficiency of two van Veen grabs. Finn. mar. Res. 248: $137-142$

Ankar, S. (1977). Digging profile and penetration of the van Veen grab in different sediment types. Contr Askö Lab. Univ. Stockh. 16: 1-22

Ankar, S., Andersin, A.-B., Lassig, J., Norling, L., Sandler, H (1979). Methods for studying benthic macrofauna. An intercalibration between two laboratories in the Baltic Sea. Finn. mar. Res. 246: 147-160

Apstein, C. (1907). Bericht über Apparate für wissenschaftliche Meeresforschung auf der Ausstellung für Meeres biologie in Marseille. Mitt. dt. SeefischVer. 23: 321-330

Axelsson, V., Håkanson, L. (1978). A gravity corer with a simple valve system. J. sedim. Petrol. 48: 630-633

Bailey, R. J. (1971). Geological sampling of the sea floor Underwat. J. 3: 110-119

Bakanov, A. I. (1979). New bottom grab designs and assess ment of the aggregation state of the benthos. Hydrobiol. J 15(3): $77-82$

Barnes, H. (1959). Oceanography and marine biology. A book of techniques. George Allen \& Unwin, London

Barnett, P. R. O., Watson, J. (1989). A comment on "Laboratory studies on core sampling with application to subtidal meiobenthos collection" (Rutledge and Fleeger). Limnol. Oceanogr. 34: 1142-1143

Barnett, P. R. O., Watson, J., Connelly, D. (1984). A multiple corer for taking virtually undisturbed samples from shelf, bathyal and abyssal sediments. Oceanol. Acta 7: 399-408

Baxter, M. S., Farmer, J. G., Mckinley, I. G., Swan, D. S., Jack, W (1981). Evidence of the unsuitability of gravity coring for collecting sediment in pollution and sedimentation rate studies. Envir. Sci. Technol. 15: 843-846

Beukema, J. J. (1974). The efficiency of the van Veen grab compared with the Reineck box sampler. J. Cons. int. Explor Mer 35: 319-327

Birkett, L. (1958). A basis for comparing grabs. J. Cons int. Explor Mer 23: 202-207 
Blomqvist, S. (1985). Reliability of core sampling of soft bottom sediment - an in situ study. Sedimentology 32: 605-612

Blomquist, S. (1990). Sampling performance of Ekman grabs in situ observations and design improvements. Hydrobiologia 206: 245-254

Blomqvist, S., Abrahamsson, B. (1985). An improved Kajaktype gravity core sampler for soft bottom sedıments. Schweiz. Z. Hydrol. 47:81-84

Blomqvist, S., Boström, K. (1987). Improved sampling of soft bottom sediments by combined box and piston coring. Sedimentology 34: 715-719

Bouma, A. H. (1969). Methods for the study of sedimentary structures. John Wiley \& Sons, New York

Bouma, A. H., Boerma, J. A. K. (1968). Vertical disturbances in piston cores. Mar. Geol. 6: 231-241

Brinkhurst, R. O. (1967). Sampling the benthos. Progress Report 32, Great Lakes Inst., University of Toronto, Ontario

Brinkhurst, R. O. (1974). The benthos of lakes. Macmillan Press, London

Burnett, B.R. (1981). Quantitative sampling of nanobiota (microbiota) of the deep-sea benthos - III. The bathyal San Diego Trough. Deep Sea Res. 28A: 649-663

Chandler, G. T., Shirley, T C., Fleeger, J. W. (1988). The tomtom corer a new design of the Kajak corer for use in meiofauna sampling. Hydrobiologia 169: 129-134

Chant, L. A., Cornett, R. J. (1990). Coring artifacts and side effects. Abstract No. 9. In: 5th int. symp. interactions between sediments and water, International Association for Sediment Water Science, 6-9 August 1990, Uppsala, Sweden

Chmelik, F. B., Bouma, A.H., Bryant, W.R. (1968). Influence of sampling on geological interpretation. Trans. Gulf Coast Ass. geol. Socs. 18: 256-263

Chodorowski, A. (1971). L'échantillonnage des peuplements d'ínvertébrés des eaux continentales stagnantes. In: Lamotte, M. Bourlière, F. (eds.) Problèmes d'écologie: l'échantillonnage des peuplements animaux des miljeux aquatiques. Masson et Cie, Paris, p. 1-51

Christie, N. D. (1975). Relationship between sediment texture, species richness and volume of sediment sampled by a grab. Mar Biol. 30: 89-96

Clarke, M. R. (1977). A brief review of sampling techniques and tools of marine biology. In: Angel, $M$. (ed.) A voyage of discovery. Pergamon Press, Oxford, p. 439-469

Craib, J. S. (1965). A sampler for taking short undisturbed marine cores. J Cons. perm. int. Explor. Mer 30: 34-39

Cummins, K.W. (1962). An evaluation of some techniques for the collection and analysis of benthic samples with special emphasis on lotic waters. Am. Midl. Nat. 67: 477-504

Dietz, R. S. (1954). Methods of exploring the ocean floor. In Isaacs, J., Iselin, C. O'D. (eds.) Symposium on oceanographic instrumentation. Natural Resources Council Publication No. 309. National Academy of Science, Division of Physical Sciences, Washington D.C., p. 194-209

Downing, J. A. (1984). Sampling the benthos of standing waters. In: Downing, J. A., Rigler, F. H. (eds.) A manual on methods for the assessment of secondary productivity in fresh waters, 2nd edn. IBP handbook No. 17. Blackwell Scientific Publications, Oxford, p. 87-130

Drake, C. M., Elliott, J. M. (1982). A comparative study of three air-lift samplers used for sampling benhic macroinvertebrates in rivers. Freshwat. Biol. 12: 511-533

Dybern, B. I., Ackefors, H., Elmgren, R. (eds.) (1976). Section 5: Benthic meiofauna. Section 6: Sampling of soft bottom macrofauna. In: Recommendations on methods for marine biological studies in the Baltic Sea. Baltic Marine Biologists Publ. 1. Askö Lab., Univ. Stockholm, Sweden, p. 51-75

Ekman, S. (1915). Die Bodenfauna des Vättern, qualitativ und quantitativ untersucht. Int. Revue ges. Hydrobiol. Hydrogr $7 \cdot 146-204,275-425$

Eleftheriou, A., Holme, N. A. (1984). Macrofauna techniques In: Holme, N.A., Mclntyre, A. D. (eds.) Methods for the study of marine benthos, 2nd edn. IBP handbook No. 16 Blackwell Scientific Publications, Oxford, p. 140-216

Elliott, J. M., Drake, C. M. (1981a). A comparative study of seven grabs used for sampling benthic macroinvertebrates in rivers. Freshwat. Biol. 11: 99-120

Elliott, J. M. Drake, C. M. (1981b). A comparative study of four dredges used for sampling benthic macroinvertebrates in rivers. Freshwat. Biol. 11 245-261

Elliott, J. M., Drake, C. M., Tullett, P. A. (1980). The choice of a suitable sampler for benthic macroinvertebrates in deep rivers. In: Graham, T.R. (ed.) Elaboration of the scientific bases for monitoring the quality of surface water by hydrobiological indicators. Pollut. Rept. No. 8. Dept. Environ. London, p. 36-44

Elliott, J. M., Tullett, P. A. (1978). A bibliography of samplers for benthic invertebrates. Occas. Publ. Freshwat. biol. Ass. No. 4, Ambleside, U.K.

Elliott, J. M., Tullett, P. A. (1983). A supplement to a bibliography of samplers for benthic invertebrates. Occas. Publ. Freshwat. biol. Ass. No. 20, Ambleside, U.K.

Elmgren, R. (1973). Methods of sampling sublittoral soft bottom meiofauna. Oikos Suppl. 15: 112-120

Elmgren, R., Radziejewska, T (eds.) (1989). Recommendations for quantitative benthic meiofauna studies in the Baltic. Baltic Marine Biologists Publ. 12. Academy of Agriculture, Szczecin, Poland

Emery, K. O., Dietz, R. S. (1941). Gravity coring instrument and mechanics of sediment coring. Bull, geol. Soc. Am. 52: $1685-1714$

Emery, K. O., Hülsemann, J. (1964). Shortening of sediment cores collected in open barrel gravity corers. Sedimentology 3: $144-154$

Evans, H. E. (1982). Gravity core sampling in Recent lake sediments: the influence of core tube diameter on recovering short cores. M.Sci. thesis, Dept. Biology, Trent University, Peterborough, Ontario

Fægri, K., Iversen, J. (1964). Textbook of pollen analysis, 2nd edn. Munksgaard, Copenhagen

Flannagan, J. F. (1970). Efficiencies of various grabs and corers in sampling freshwater benthos. J. Fish. Res. Bd Can. 27: 1691-1700

Fleeger, J. W., Thistle, D., Thiel, H. (1988). Sampling equipment. In: Higgins, R. P., Thiel, $H$. (eds.) Introduction to the study of meiofauna. Smithsonian Institution Press, Washington, D.C., p. 115-125

Fowler, G. A., Kulm, L. D. (1966). A multiple corer. Limnol Oceanogr. 11: 630-633

Frithsen, J. B., Rudnick, D. T., Elmgren, R. (1983). A new, flow-through corer for the quantitative sampling of surface sediments. Hydrobiologia 99: 75-79

Fuller, C. M., Butman, C. A. (1988). A simple technique for fine-scale, vertical sectioning of fresh sediment cores. $\mathrm{J}$. sedim. Petrol. 58: 763-768

Gallardo, V A. (1965). Observations on the biting profiles of three $0.1 \mathrm{~m}^{2}$ bottom-samplers. Ophelia 2: 319-322

Gooday, A. J. (1986). Meiofaunal foraminiferans from the bathyal Porcupine Seabight (northeast Atlantic): size structure, standing stock, taxonomic composition, species diversity and vertical distribution in the sediment. Deep Sea Res. 33: 1345-1373

Gooday, A. J. (1988). A response by benthic Foraminifera to the deposition of phytodetritus in the deep sea. Nature, Lond. 332: 70-73 
Gunter, G. (1957). Dredges and trawls. Mem. geol. Soc. Am. $67: 73-80$

Hakala. I. (1971). A new model of the Kajak bottom sampler, and other improvements in the zoobenthos sampling technique. Annls zool. fenn. 8: 422-426

Hăkanson, L., Jansson, M. (1983). Principles of lake sedimentology. Springer-Verlag, Berlin

Hamilton, A. L., Burton, W., Flannagan, J. F. (1970). A multiple corer for sampling profundal benthos. J. Fish Res. Bd Can. 27: 1867-1869

Harrison, W., Lynch, M. P., Altschaeffl, A. G. (1964). Sediments of lower Chesapeake Bay, with emphasis on mass properties. J. sedim. Petrol. 34: 727-755

Harvey, B. R., Lovett, M. B., Boggis, S. J. (1987). Some experiences in controlling contamination of environmental materials during sampling and processing for low-level actinide analysis. J. Radioanal. Nucl. Chem. 115: 357-368

Hellawell, J. M. (1978). Biological surveillance of rivers. A biological monitoring handbook. Water Research Centre, Stevenage, U. K.

Hellawell, J. M. (1986). Biological indicators of freshwater pollution and environmental management. Elsevier Applied Science Publishers, London

Hessler, R. R., Jumars, P. A. (1974). Abyssal community analysis from replicate box cores in the central North Pacific Deep Sea Res. 21. 185-209

Hollister, C. D., Silva, A. J., Driscoll, A. (1973). A giant pistoncorer. Ocean Engng 2: 159-168

Holme, N. (1951). Sampling the sea-bed. Discovery, Lond. 12: $59-63$

Holme, N. A. (1964). Methods of sampling the benthos. In Russell, F. S. (ed.) Adv. mar Biol. 2: 171-260

Holme, N. A. (1971). Macrofauna sampling. In: Holme, N. A., McIntyre, A. D. (eds.) Methods for the study of marine benthos. IBP handbook No. 16. Blackwell Scientific Publications, Oxford, p. 80-130

Hongve, D., Erlandsen, A. H. (1979). Shortening of surface sediment cores during sampling. Hydrobiologia 65: 283-287

Hopkins, T L. (1964). A survey of marine bottom samplers. Prog. Oceanogr. 2: 213-256

Hough, J. L. (1939). Bottom-sampling apparatus. In: Trasker, P. D. (ed.) Recent marine sediments. American Association of Petroleum Geologists, Tulsa, Oklahoma, p. 631-664

Hulings, N. C., Gray, J. S. (1971). A manual for the study of the meiofauna. Smithson. Contr Zool. 78: 1-83

Hurlbert, S. H. (1984). Pseudoreplication and the design of ecological field experiments. Ecol. Monogr. 54: 187-211

Hvorslev, M. J. (1949). Subsurface exploration and sampling of soils for civil engineering purposes. U. S. Army Corps of Engineers, Waterways Experimental Station, Vicksburg, Mississippi

Hvorslev, M. J., Stetson, H. C. (1946). Free-falling coring tube a new type of gravity bottom sampler. Bull. geol. Soc. Am. 57: $935-949$

Igarashi, Y., Ridion, J. B., Campbel], J. R., Allman, R. L. (1970) Note on a mode of piston core disturbance. J. sedim. Petrol. 40: $1351-1355$

Inderbitzen. A. L. (1968). A study of the effects of various core samples on mass physical properties in marine sediments. J. sedim. Petrol. 38: 473-489

Ingri, J. (1985). Distribution, composition and ongin of ferromanganese concretions in the Gulf of Bothnia. In: Ingri, J. Geochemistry of ferromanganese concretions and associated sediments in the Gulf of Bothnia, Paper 1. Doctoral Thesis, Lulea University of Technology, Luleå, Sweden. $374 \mathrm{p}$.
Jensen, P. (1983). Meiofauna abundance and vertical zonation in a sublittoral soft bottom, with a test of the Haps corer. Mar. Biol. 74: 319-326

Jumars, P. A. (1975a). Methods for measurement of community structure in deep-sea macrobenthos. Mar. Biol. 30: $245-252$

Jumars, P. A. (1975b). Environmental grain and polychaete species diversity in a bathyal benthic community. Mar. Biol. 30: 253-266

Jumars, P. A., Eckman, J. E. (1983). Spatial structure within deep-sea benthic communities. In: Rowe, G. T. (ed.) Deepsea biology. The sea, Vol. 8. John Wiley \& Sons, New York, p. $399-451$

Kajak, Z. (1971). Survey of samplers. In: Edmonson, W. T. Winberg, G. G. (eds.) A manual on methods for the assessment of secondary productivity in fresh waters. IBP handbook No. 17 Blackwell Scientific Publications, Oxford, p. $25-57$

Kallstenius, T. (1958). Mechanical disturbances in clay samples taken with piston samplers. Roy. Swed. geotech. Inst. Proc. 16: 1-75

Kemp, A. L. W., Savile, H. A., Gray, C. B., Mudrochova, A. (1971). A simple corer and a method for sampling the mudwater interface. Limnol. Oceanogr. 16: 689-694

Kjellman, W., Kallstenius, T., Wager, O. (1950). Soil sampler with metal foils. Device for taking undisturbed samples of very great length. Roy. Swed. geotech. Inst. Proc. 1: 1-76

Kögler, F.-C. (1963). Das Kastenlot. Meyniana 13: 1-7

Krogh, A., Spärck, R. (1936). On a new bottom-sampler for investigation of the micro fauna of the sea bottom, with remarks on the quantity and significance of the benthonic micro fauna. Biol. Medd., K. Dan. Vidensk. Selsk. 13(4): $1-12$

Kullenberg, B. (1944). Nya försök att upphämta långa sedimentprofiler från havsbottnen. 1. Kolvlodet. Geol. Fören. Stockh. Förhandl. 66: 501-504

Kullenberg, B. (1945). Nya svenska profillod. Medd. Dansk Geol. Foren. 10: 557-560

Kullenberg, B. (1947). The piston core sampler. Svenska hydrogr.-biol. Komm. Skr., Tredje Ser., Hydrografi, Bd. 1(2): $12-46$

Kullenberg, B. (1955). Deep-sea coring. Rept. Swed. Deep-Sea Exped. 4(1): 37-96

Lebel, J., Silverberg, N., Sundby, B. (1982). Gravity core shortening and pore water chemical gradients. Deep Sea Res. 29: 1365-1372

Leonard, E. (1990). An assessment of sediment loss and distortion at the top of short gravity cores. Sedimentary Geol. 66: $57-63$

Lie, U., Pamatmat, M. M. (1965). Digging characteristics and sampling efficiency of the $0.1 \mathrm{~m}^{2}$ van Veen grab. Limnol. Oceanogr 10: 379-384

Livingstone, D. A. (1967). The use of filament tape in raising long cores from soft sediment. Limnol. Oceanogr. 12: 346-348

Livingstone, D. A. (1990). The design of sediment coring tubes and its relevance to "Laboratory studies on core sampling with application to subtidal meiobenthos collection" (Rutledge and Fleeger). Limnol. Oceanogr 35: 543-545

Longhurst, A. R. (1964). A review of the present situation in benthic synecology. Bull. Inst. océanogr. Monaco 63(1317): $1-54$

Lundbeck, J. (1926). Die Bodentierwelt norddeutscher Seen. Arch. Hydrobiol. Suppl. 7: 1-473

Lundqvist, G. (1922). Principerna for rörlodens arbetssätt. Geol. Fören. Stockh. Förhandl. 44: 591-606. (In Swedish; German summary) 
Lundqvist, G. (1923). Några nya rörlodtyper. Skr söd. Sver. Fiskför. 1923: 34-46 (In Swedish; German summary)

Lundqvist, G. (1925). Methoden zur Untersuchung der Entwicklungsgeschichte der Seen. In: Abderhalden, E. (ed.) Handbuch der biologischen Arbeitsmethoden 9 (2). Methoden der Erforschung der Leistungen des tierischen Organismus. Methoden der Süwasserbiologie. Urban \& Schwarzenberg, Berlin, p. 427-462

Maitland, P. S., Morris, K. H. (1978). A multi-purpose modular limnological sampler. Hydrobiologia 59: 187-195

McCoy, F. W. Jr. (1972). An analysis of piston coring through corehead camera photography. In: Underwater soil sampling, testing, and construction control. Am. Soc. Test. Mater., spec. tech. Pub]. 501: 90-105

McCoy, F. W. (1980). Photographic analysis of coring. Mar Geol. 38: 263-282

McCoy, F. W. (1985). Mid-core flow-in: implications for stretched stratigraphic sections in piston cores. $J$. sedim. Petrol. 55: 608-610

McCoy, F. W., von Herzen, R. P. (1971). Deep-sea corehead camera photography and piston coring. Deep Sea Res. 18 $361-373$

McIntyre, A. D. (ed.) (1970). Bibliography on methods of studying the marine benthos. FAO Fish. tech. Pap. 98: $1-96$

McIntyre, A. D. (1971a). Meiofauna and microfauna sampling. In: Holme, N. A., McIntyre, A. D. (eds.) Methods for the study of marine benthos. IBP handbook No. 16. Blackwell Scientific Publications, Oxford, p. 131-139

McIntyre, A. D. (1971b). Deficiency of gravity corers for sampling meiobenthos and sediments. Nature, Lond. 231: 260

McIntyre, A. D., Warwick, R. M. (1984). Meiofauna techniques. In: Holme, N. A., McIntyre, A. D. (eds.) Methods for the study of marine benthos, 2nd edn. IBP handbook No. 16. Blackwell Scientific Publications, Oxford, p. $217-244$

Meischner, D., Rumohr, J. (1974). A light-weight, highmomentum gravity corer for subaqueous sediments. Senckenberg. marit. 6: 105-117

Milbrink, G. (1971). A simplified tube bottom sampler. Oikos 22: $260-263$

Moore, T C. Jr., Heath, G. R. (1978). Sea-floor sampling techniques. In: Riley, J. P., Chester, R. (eds.) Chemical oceanography, 2nd edn, Vol. 7. Academic Press, London, p. $75-126$

Naumann, E. (1917). Om profillodning i gyttje- och dyavlagringar. Sver. geol. Unders. Ser. C: 10(5): 1-31. (In Swedish; German summary)

Naumann, E. (1930). Einführung in die Bodenkunde der Seen. In: Thienemann, A. (ed.) Die Binnengewässer 9. E. Schweizerbartsche Verlagsbuchhandlung, Stuttgart

Nevissi, A. E., Shott, G. J., Crecelius, E. A. (1989). Comparison of two gravity coring devices for sedimentation rate measurement by ${ }^{210} \mathrm{~Pb}$ dating techniques. Hydrobiologia 179: 261-269

Noorany, I. (1972). Underwater soil sampling and testing - a state-of-the-art review. Underwater soil sampling, testing, and construction control. Am. Soc. Test. Mater., spec. tech. Publ. 501: 3-41

Olsson, J. (1925). Kolvborr, ny borrtyp för upptagning av lerprov. Tek. Tidskr., Väg- och vattenbyggnadskonst 55: $13-16$

Olsson, J. (1938). Method for taking earth samples with the most undisturbed natural consistency. Trans. Second Congr. Large Dams, Vol. 4. U.S. Government Printing Office, Washington, D.C., p. 157-161
Petersen, C. G. J. (1913). Havets bonitering. II. Om havbundens dyresamfund og om disses betydning for den marine zoogeografi. Beretning til Landbrugsministeriet fra Den danske biologiske Station 21, 1-42 plus addendum 1-68 Copenhagen

Petersen, C. G. J., Jensen, P. B. (1911). Havets bonitering. I. Havbundens dyreliv, dets næring og mængde. Beretning til Landbrugsministeriet fra Den danske biologiske Station 20: 1-78. Copenhagen

Pfannkuche, O. (1985). The deep-sea meiofauna of the Porcupine Seabight and abyssal plain (NE Atlantic): population structure, distribution, standing stocks. Oceanol. Acta 8: $343-353$

Piggot, C. S. (1941). Factors involved in submarine core sampling. Bull. geol. Soc. Am. 52: 1513-1523

Powers, C. F., Robertson, A. (1967). Design and evaluation of an all-purpose benthos sampler. In: Ayers, J. C., Chandler D. C. (eds.) Studies on the environment and eutrophication of Lake Michigan. Spec. Rept. 30, Great Lakes Res. Div. University of Michigan, Ann Arbor, p. 126-131

Pratje, O. (1924). Fortschritte in der Erforschung des Meeresbodens. Der Geologe 35: 703-711

Pratje, O. (1934). Sind die Bodenprofile aus den Röhrenloten ohne Unterbrechungen? Versuche über die Arbeitsweise der Röhrenlote. Annln Hydrogr. mar Met. 62: 137-144

Pratje, O. (1935). Die Sedimente des Südatlantischen Ozeans. Gewinnung und Bearbeitung der Bodenproben. Wissenschaftliche Ergebnisse der Deutschen Atlantischen Expedition auf dem Forschungs- und Vermessungsschiff "Meteor" 1925-1927, Band 3, Teil 2. Verlag von Walter de Gruyter und Co., Berlin, p. 1-56

Pratje, O. (1938). Gewinnung und Untersuchung der Meeresgrundproben. In: Abderhalden, E. (ed.) Handbuch der biologischen Arbeitsmethoden 9 (6:2). Methoden der Meerwasserbiologie. Urban \& Schwarzenberg, Berlin, p. $381-542$

Pratje, O. (1950a). Die Erfahrungen bei Gewinnung von rezenten, marinen Sedimenten in den letzten 25 Jahren. Mitt. geogr. Ges. Hamburg 49: 118-197

Pratje, O. (1950b). Eine neue Lotröhre und ihre erste Erprobung. Dt. hydrogr Z. 3: 100-107

Renberg, I. (1981a). Improved methods for sampling, photographing and varve-counting of varved lake sediments. Boreas 10: 255-258

Renberg, I. (1981b). Formation, structure and visual appearance of iron-rich, varved lake sediments. Verh. int. Verein. Limnol. 21: 94-101

Renberg, I. (1982). Varved lake sediments - geochronological records of the Holocene. Geol. Fören. Stockh. Förhandl 104: $275-279$

Renberg, I. (1986a). Varved lake sediments and environmental monitoring. National Swedish Environment Protection Board, Rept. 3083, Solna, Sweden. (In Swedish; English abstract)

Renberg, I. (1986b). Photographic demonstration of the annual nature of a varve type common in $\mathrm{N}$. Swedish lake sediments. Hydrobiologia 140: 93-95

Renberg, I. (1986c). Concentration and annual accumulation values of heavy metals in lake sediments: their significance in studies of the history of heavy metal pollution. Hydrobiologia 143: 379-385

Renberg, I., Wik, M. (1985). Carbonaceous particles in lake sediments - pollutants from fossil fuel combustion. Ambio 14: 161-163

Resh, V H. (1979). Sampling variability and life history features: basic considerations in the design of aquatic insect studies. J. Fish. Res. Bd Can. 36: 290-311 
Reys, J.-P., Salvat, B. (1971). L'échantillonnage de la macrofaune des sédiments meubles marins. In: Lamotte, M. Bourlière, F. (eds.) Problèmes d'écologie: l'échantillonnage des peuplements anımaux des milieux aquatiques. Masson et Cie, Paris, p. 185-242

Richards, A. F. (1961). Investigations of deep-sea sediment cores. 1 Shear strength, bearing capacity, and consolidation. U.S. Navy Hydrographic Office, Tech. Rept 63, Washington, D.C

Richards, A. F., Keller, G. H. (1961). A plastic-barrel sediment corer. Deep Sea Res. 8: 306-312

Richards, A. F., Parker, H. W. (1968). Surface coring for shear strength measurements. Proc. Conf. Civil Engineering Oceans. American Society of Civil Engineers, New York, p. $445-489$

Riddle, M. J. (1989). Bite profiles of some benthic grab samplers. Estuar. coast. Shelf Sci. 29: 285-292

Rosenberg, D. M. (1978). Practical sampling of freshwater macrozoobenthos: a bibliography of useful texts, reviews, and recent papers. Canadian Fisheries and Marine Service, Can. Fish. Mar. Serv. Tech. Rept. 790, Winnipeg, Manitoba

Rosfelder, A. M., Marshall, N. F. (1967). Obtaining large, undisturbed, and orientated samples in deep water. In. Richards, A. F. (ed.) Marine geotechnique. University of Illinois Press, Urbana, Illinois, p. 243-263

Ross, D. A., Riedel, W. R. (1967). Comparison of upper parts of some piston cores with simultaneously collected openbarrel cores. Deep Sea Res. 14: 285-294

Rudnick, D. T., Elmgren, R., Frithsen, J. B. (1985). Meiofaunal prominence and benthic seasonality in a coastal marine ecosystem. Oecologia 67: 157-168

Rutledge, P. A., Fleeger, J. W (1988). Laboratory studies on core sampling with application to subtidal meiobenthos collection. Limnol. Oceanogr. 33: 274-280

Rutledge, P. A., Fleeger, J. W (1989). Reply to comment by Barnett and Watson. Limnol. Oceanogr. 34: 1143-1144

Saarnisto, M. (1986). Annually laminated lake sediments. In: Berglund, B. E. (ed.) Handbook of Holocene palaeoecology and palaeohydrology. John Wiley \& Sons, Chichester, p. $343-370$

Schlieper, C. (1968). Methoden der meeresbiologischen Forschungen. Gustav Fischer Verlag, Jena

Schwoerbel, J. (1986). Methoden der Hydrobiologie. Süßwasserbiologie, 3rd edn. Gustav Fischer Verlag, Stuttgart

Seyb, S. M., Hammond, S. R., Gilliard, I. (1977). A new device for recording the behavior of a piston corer. Deep Sea Res. 24: $943-950$

Shepard, F. P. (1973). Submarine geology, 3rd edn. Harper \& Row Publishers, New York

Sly, P. G. (1969). Bottom sediment sampling. Proc. Conf. Gt Lakes Res. (Inst. Sci. Technol., Univ. Mich., Ann Arbor) 12: 883-898

Sly, P. G. (1981). Equipment and techniques for offshore survey and site investigations. Can. geotech. J. 18: $230-249$

Smith, W., McIntyre, A. D. (1954). A spring-loaded bottomsampler J. mar. biol. Ass. U.K. 33: 257-264

Snider, L. J., Burnett, B. R., Hessler, R. R. (1.984). The composition and distribution of meiofauna and nanobiota in a

This review was submitted to the editor central North Pacific deep-sea area. Deep Sea Res. 31. $1225-1249$

Southwood, T R. E. (1978). Ecological methods, with particular reference to the study of insect populations, 2nd edn. Chapman and Hall, London

Steiner, G. (1919). Untersuchungsverfahren und Hilfsmittel zur Erforschung der Lebewelt der Gewässer. Handbuch der mikroskopischen Technik. Frank'sche Verlagshandlung, Stuttgart

Stowe, D. A. V., Aksu, A. E. (1978). Disturbances in soft sediments due to piston coring. Mar. Geol. 28: 135-144

Thiel, H. (1983). Meiobenthos and nanobenthos of the deep sea. In: Rowe, G. T. (ed.) Deep-sea biology. The sea, Vol. 8. John Wiley \& Sons, New York, p. 167-230

Thiel, H., Pfannkuche, O., Schriever, G., Lochte, K., Gooday, A. J., Hemleben, C., Mantoura, R. F. G., Turley, C. M., Patching, J. W., Riemann, F. (1988/1989). Phytodetritus on the deep-sea floor in a central oceanic region of the northeast Atlantic. Biol. Oceanogr. 6: 203-239

Thorson, G. (1957). Sampling the benthos. Mem. geol. Soc. Am. 67: 61-73

Twenhofel, W. H., Tyler, S. A. (1941). Methods of study of sediments. McGraw-Hill Book Company, New York

Ursin, E. (1954). Efficiency of marine bottom samplers of the van Veen and Petersen types. Medd. Dan. Fisk. Havunders. $1(7): 1-8$

Valle, K. J. (1927), Ökologisch-limnologische Untersuchungen über die Boden- und Tiefenfauna in einigen Seen nördlich vom Ladoga-See, I. Acta zool. fenn. 2: 1-179

Veen, J. van (1933). Onderzoek naar het zandtransport von rivieren. De Ingenieur 48B: 151-159

Wasmund, E. (1932). Entwicklung und Verbesserung der Entnahmeapparatur für Bodenproben unter Wasser. Arch. Hydrobiol. 23: 646-662

Weaver, P. P. E., Schultheiss, P. J. (1983). Detection of repenetration and sediment disturbance in open-barrel gravity cores. J. sedim. Petrol. 53: 649-654

Welch, P. S. (1948). Limnological methods. McGraw-Hill Book Company, New York

Wells, J. B. J. (1971). A brief review of methods of sampling the meiobenthos. Smithson. Contr. Zool. 76: 183-186

Wigley, R. L. (1967). Comparative efficiencies of van Veen and Smith-McIntyre grab samplers as revealed by motion pictures. Ecology 48: 168-169

Willemoës, M. (1964). A ball-stoppered quantitative sampler for the microbenthos. Ophelia 1. 235-240

Wrath, W. F. (1936). Contamination and compaction in core sampling. Science 84: 537-538

Wright, H. E. Jr. (1980). Cores of soft lake sediments. Boreas 9 : 107-114

Wright, H. E., Cushing, E. J., Livingstone, D. A. (1965). Coring devices for lake sediments. In: Kummel, B., Raup, D. (eds.) Handbook of paleontological techniques. W. H. Freeman \& Company, San Francisco, p. 494-520

Wundsch, H. H. (1924). Die quantitative Untersuchung der Bodenfauna und -flora in ihrer Bedeutung für die theoretische und angewandte Limnologie. Verh. int. Verein. Limnol. 2: 13-52

Yates, F. (1981). Sampling methods for censuses and surveys, 4 th edn. Charles Griffin \& Company, High Wycombe, U.K.

Manuscript first received: October 5, 1990 Revised version accepted: March 13, 1991 